\title{
REFORMASI BIROKRASI PERPAJAKAN SEBAGAI USAHA PENINGKATAN PENDAPATAN NEGARA DARI SEKTOR PAJAK
}

\author{
Pranoto, Ayub Torry Satriyo Kusumo \\ Fakultas Hukum Universitas Sebelas Maret \\ Email:maspran7@gmail.com; ayub.kusumo@gmail.com
}

\begin{abstract}
The main concern of this article are, First, describing tax modernization; and Second, constructing a model of the Community Compliance of Paying Taxes. Taxes, based on Indonesia's Law Number 28 of 2007 are compulsory contributions to the state which are indebted by individual or organization body, obliged based on Act, without any direct compensation, and spent by the state for the most prosperity of the community. There are a lot of a tax functions, such as infrastructure maintenance and educational operation. Thus, the augmentation of awareness in paying taxes can be done through the formal education. This research method is an empirical research, using the primary and secondary data. The result of this research indicate that a practice of modernization and reformation in taxation. It is supported with the construction of curricula which include the matter of taxation for the elementary and secondary education. Realization of the awareness for paying taxes is the collective task of the government, community, as well as the relevant stakeholders.
\end{abstract}

Keywords: Tax, Harmonization of tax regulations, Awareness for paying taxes, formal education.

Abstrak

Perhatian utama dari artikel ini adalah , Pertama, menggambarkan modernisasi pajak ; dan Kedua , membangun model Kepatuhan Komunitas Membayar Pajak . Pajak, berdasarkan Undang-Undang Nomor 28 Tahun 2007 adalah pungutan wajib kepada negara yang terhutang oleh individu atau organisasi badan hukum, wajib berdasarkan Undang-Undang, tanpa kompensasi langsung, dan menghabiskan oleh negara untuk sebagian besar kesejahteraan masyarakat . Ada banyak fungsi pajak, seperti pemeliharaan infrastruktur dan operasi pendidikan . Dengan demikian, augmentasi kesadaran dalam membayar pajak dapat dilakukan melalui pendidikan formal. Metode penelitian ini adalah penelitian empiris, dengan menggunakan data primer dan sekunder. Hasil penelitian ini bahwa praktik modernisasi dan reformasi di bidang perpajakan. Hal ini didukung dengan pembangunan kurikulum yang meliputi soal perpajakan untuk pendidikan dasar dan menengah . Realisasi kesadaran untuk membayar pajak adalah tugas kolektif dari pemerintah, masyarakat, serta pemangku kepentingan terkait. 
Kata Kunci: Pajak, Harmonisasi Aturan Perpajakan, Kepedulian Membayar Pajak, Pendidikan formal

\section{A. Pendahuluan}

Pajak merupakan pungutan wajib tanpa kontraprestasi yang digunakan antara lain untuk membiayai pengeluaran publik, penyelengaraan pemerintahan, pembangunan fasilitas infrastruktur, pemeliharaan pendidikan, gaji aparatur negara, pemeliharaan fasilitas kesehatan, dan sumber terbesar dalam Anggaran Pendapatan dan Belanja Negara (APBN), sekitar 73,71\% (Undang-Undang Nomor 41 Tahun 2008). Kepatuhan perpajakan yakni suatu keadaan wajib pajak (WP) memenuhi semua kewajiban dan hak perpajakannya antara lain membayar sebelum batas waktunya.

Paradigma selama ini pajak dianggap sebagai suatu yang menakutkan, yaitu dengan pembayaran nominal uang yang cukup besar dan digunakan untuk kepentingan negara (Bird. Richard, and Oliver Oldman, 1964 : 25). Hal tersebut menurut masyarakat tidak sebanding dengan pendapatan yang didapat dan tidak sebanding pula dengan pelayanan yang didapat oleh masyarakat. Sehubungan dengan hal di atas, maka perlu dilakukan pergeseran (reorientasi) paradigma tentang pajak yaitu pergeseran pandangan dari anggapan pajak hanya sebagai beban dan ketakutan masyarakat menjadi pandangan yang menempatkan pajak dan memahami secara keseluruhan baik keuntungan maupun peran pajak bagi bangsa dan negara.

Pergeseran pandangan ini tentu saja menuntut perubahan pembelajaran pajak tidak hanya dikonsentrasikan pada pendidikan tinggi saja tetapi juga perlu diajarkan pada siswa di pendidikan dasar dan menengah. Untuk meningkatkan kepatuhan dalam diri wajib pajak, maka pendidikan memegang peran yang amat penting, karena dengan pendidikan masyarakat dapat mengerti pentingnya kegunaan pajak. Pemahaman akan pentingnya perpajakan/hukum pajak perlu terus dipupuk dari pendidikan dasar.

Berdasarkan latar belakang yang telah diuraikan di atas, maka permasalahan yang diteliti dalam artikel ini adalah sebagai berikut:

1. Apa yang menyebabkan rendahnya kesadaran masyarakat untuk membayar pajak? 
2. Bagaimana upaya untuk meningkatan kesadaran masyarakat untuk membayar pajak?

\section{B. Metode Penelitian}

Tulisan ini merupakan hasil penelitian hukum empiris dengan pendekatan kasus dan konseptual. Sedangkan jika dilihat dari sifatnya termasuk penelitian preskriptif, dengan menggunakan data primer dan sekunder. Tulisan ini merupakan hasil penelitian lapangan dengan pendekatan perundang-undangan dan pendekatan konseptual.

\section{Hasil Penelitian dan Pembahasan}

1. Jenis-Jenis Pajak, dan Fungsinya

Pajak adalah iuran rakyat kepada kas negara (peralihan kekayaan dari sektor partikelir ke sektor pemerintah) berdasarkan undang-undang (dapat dipaksakan) dengan tiada mendapat jasa timbal (tangen prestatie) yang langsung dapat ditunjuk dan yang digunakan untuk membiayai pengeluaran umum (publieke uitgaven) (Rochmat Soemitro, 1990 : 22). Definisi tersebut disempurnakan bahwa pajak sebagai : kas negara untuk membiayai pengeluaran rutin dan "Surplus"nya digunakan untuk "Public Saving" yang merupakan sumber utama untuk membiayai "Public Invesment"(Hector S. De Leon, 1993 : 13). Sedangkan Anderson W.H, memberikan definisi : Tax is a compulsory contribution, levied by the state upon persons property income and privileges for purposes of defraying the expences of government (Anderson WH, $1981: 21$ ).

Mengacu dari definisi tersebut, terdapat pembagian jenis pajak dalam berbagai kelompok sebagai berikut. :

1. Pembagian menurut administrasi yuridis terdiri atas pajak langsung dan pajak tidak langsung, di mana kedua jenis tersebut dibagi lagi kedalam dua segi lain, yaitu dari segi yuridis dan ekonomis

a. Dari segi yuridis, maka jenis pajak dapat dikelompokkan dalam :

1) Pajak Langsung, yaitu pajak-pajak yang harus dipikul sendiri oleh Wajib Pajak yang bersangkutan dan tidak dapat dilimpahkan 
kepada orang lain serta dikenakan secara berulang-ulang pada waktu-waktu tertentu (periodik) berdasarkan Surat Ketetapan Pajak atau Kohir (tindasan Surat Ketetapan Pajak). Termasuk dalam pajak langsung ini contohnya Pajak Penghasilan (PPh)

2) Pajak Tidak Langsung, yaitu suatu pajak yang dipungut sekali ketika apa yang dikendaki undang-undang dipenuhi (tidak menggunakan kohir), contohnya Pajak Pertambahan Nilai (PPN) dan Bea Materai.

b. Dari segi ekonomis, dikatakan sebagai pajak langsung apabila beban pajak tidak dapat dilimpahkan pada pihak lain, contohnya Pajak Penghasilan (PPh). Sedangkan pajak tidak langsung merupakan jenis beban pajak di mana pihak wajib pajak dapat mengalihkan beban pajaknya kepada orang lain, contohnya Pajak Pertambahan Nilai (PPN)

2. Pembagian menurut sifatnya terdiri atas :

a. Pajak yang bersifat pribadi (persoonlijk), yaitu pajak-pajak yang pemungutannya berpangkal pada diri orangnya (pribadi), keadaan diri wajib pajak dapat mempengaruhi besar kecilnya jumlah pajak yang harus dibayar atau memperhatikan daya pikul, contohnya Pajak Penghasilan

b. Pajak Objektif atau pajak yang bersifat kebendaan (zakelijk), yaitu pajak-pajak yang pemungutannya berpangkal pada objeknya, perbuatan dan kejadian yang dilakukan atau terjadi dalam wilayah negara dengan tidak mengindahkan keadaan diri dan keadaan wajib pajak, contohnya Bea Materai

3. Pembagian berdasarkan titik tolak pungutannya, yang terdiri atas:

a. Pajak subjektif, yaitu pajak yang pengenaanya berpangkal pada orang atau badan yang dikenai pajak (wajib pajak). Subjek dalam hal ini adalah orang pribadi, badan, dan bentuk usaha tetap. Setelah ditentukan subjeknya, baru kemudian dilihat apakah mereka 
mempunyai atau memperoleh penghasilan yang memenuhi syarat untuk dikenai pajak.

b. Pajak objektif, yaitu pajak yang pengenaannya berpangkal pada objek yang dikenai pajak, dan untuk mengenakan pajaknya harus dicari subjeknya. Contohnya Pajak Bumi dan Bangunan (PBB) di mana yang pertama kali ditentukan adalah objek (bumi dan bangunan) baru kemudian dicari siapa yang menjadi subjek pajaknya.

4. Pembagian berdasarkan lembaga pemungutannya (kewenangan memungut) yang terdiri dari :

1). Pajak negara atau pusat, yaitu pajak yang dipungut oleh pemerintah pusat, yang penyelenggaraan pemungutannya di daerah-daerah dilakukan oleh Kantor Inspeksi Pajak setempat (sekarang dinamakan Kantor Pelayanan Pajak), dan hasilnya digunakan untuk pembiayaan rumah tangga negara pada umumnya. Contoh: Pajak Penghasilan (PPh), Pajak Pertambahan Nilai atas Barang dan Jasa dan Pajak Penjualan atas Barang Mewah (PPN dan PPn BM), Bea Materai, Cukai.

2). Pajak Daerah, yaitu pajak yang wewenang pemungutannya berada pada pemerintah daerah, baik tingkat Propinsi (contoh: Pajak Kendaraan Bermotor, Pajak Balik Nama Kendaraan Bermotor) atau Kabupaten/ Kota (contoh: Pajak Hotel, Pajak Restoran, Pajak Hiburan, Pajak Reklame, Pajak Parkir) yang hasil pemungutannya digunakan untuk pembiayaan rumah tangga daerah.

Tujuan pajak itu mempunyai hubungan erat dengan tujuan negara, dan bersumber dan berakar pada tujuan masyarakat, yaitu suatu cita-cita hidup yang tumbuh dan terkandung di dalam masyarakat untuk dicapai dan direalisasi oleh negara sebagai alat perjuangan dan organisasi masyarakat yang tertinggi. Tujuan masyarakat inilah yang menjadi filsafat bangsa dan filsafat negara sehingga pajak tanpa tujuan masyarakat itu tidak akan mungkin dapat menunaikan tugasnya yang selaras dan seirama dengan apa 
yang telah menjadi tujuan masyarakat (Glenn P. Jenkins dan Gangadhar P. Shukla, 1997 22).

Mengingat betapa pentingnya pajak dalam suatu negara, maka fungsi pajak pada umumnya dapat dibedakan dalam dua hal, yaitu : fungsi budgetair yaitu tujuan primernya untuk mengisi kas negara dan fungsi Regulerend yaitu pajak digunakan mengatur berbagai macam kebijakan dalam membentuk kemakmuran masyarakat melalui pajak-pajak.

\section{Asas-Asas Pemungutan Pajak}

Adam Smith memberikan prinsip tentang asas atau syarat-syarat pemungutan pajak yang patut dipedomani oleh semua negara, yang dikenal sebagai Adam Smith's Canons dan Smith's Canons ini meliputi empat prinsip (four maxims) yang meliputi:

1. Equality atau persamaan artinya, tidak boleh ada diskriminasi dalam pemungutan pajak, oleh karena itu orang dalam keadaan yang sama harus dikenakan pajak yang sama dan tidak boleh ada mengenakan pajak yang tidak sesuai dengan undang-undang atau tidak boleh ada penyimpangan dari Undang-undang. Asas ini menuju kepada keadilan, karena semua bentuk pemungutan pajak oleh negara haruslah berdasarkan undangundang dan pada undang-undang inilah yang menjamin kepastian hukumnya.

2. Certainly atau kepastian yaitu kepastian yang berhubungan dengan hukum dan bukan arti kepastian yang didasarkan kepada kesewenang-wenangan. Dengan demikian maka kepastian itu haruslah dapat memberi :

a. Jaminan hukum yang berupa perlindungan terhadap wajib pajak;

b. Arti pasti yang menjadi objek pajaknya;

c. Arti kepastian hukum mengenai subjeknya, maka undang-undang harus menguraikan secara tegas dan pasti;

d. Kepastian mengenai jumlah pajak yang harus dibayar dan bila tarif dibuat golongan-golongan harus pasti;

e. Kepastian mengenai cara dan saat / waktu untuk membayar pajak. 
3. Convenience of payment artinya pajak harus dipungut dari wajib pajak pada waktu setepat-tepatnya, misalnya pada waktu panen atau pada waktu mendapatkan penghasilan dan sebagainya.

4. Economic in collection artinya pajak harus dipungut dengan biaya serendah-rendahnya (seminimal mungkin) dan hasilnya mempunyai arti.

Adolf Wagner memberikan pandangannya tentang asas pemungutan pajak (Adolf Wagner dalam Sindian Isa D, 1995 : 18) adalah, yang mengemukakan adanya empat asas dalam pemungutan, antara lain:

1. Dalam bidang finansial-politis dimana asas ini mempunyai pengertian bahwa pemungutan pajak untuk mencukupi keuangan negara dan mudah dilaksanakan.

2. Dalam bidang ekonomis dimana asas ini berhubungan erat dengan sumbersumbernya, akibat-akibat pajak.

3. Asas keadilan yang dapat diartikan sebagai pengertian equitable yang berlaku secara umum dan merata.

4. Asas dalam bidang administrasi yang berarti harus pasti, tepat dan tidak memakan biaya banyak.

Atas dasar itulah Wagner menyusun asas-asas itu dari berbagai sudut, yaitu sudut financial-politis, ekonomis, keadilan dan administratif. Rochmat Soemitro lebih menyukai cara pemungutan pajak ditinjau dari sudut finansial-politis, ekonomis, keadilan, dan tata usaha seperti yang dilakukan oleh Wagnerr, akan tetapi menurut beliau asas yang terutama dan tertinggi adalah asas keadilan untuk mencapai kesejahteraan umum (Rochmat Soemitro, 1992 10). Sebab jika sesuatu pajak ditinjau dari sudut ekonomi dan keuangan menguntungkan serta teknik pemungutan pajak mudah dilaksanakan, tetapi jika tidak adil dan hanya menguntungkan beberapa gelintir orang tertentu saja atau terlalu memberatkan beban orang yang tidak mampu, maka pajak yang demikian itu jangan dilaksanakan.

Dari beberapa uraian tentang asas-asas dalam pemungutan pajak, penulis berpendapat bahwa ada empat asas utama dalam pemungutan pajak yaitu: 
1. Asas yuridis dalam arti bahwa setiap pemungutan pajak yang dijalankan oleh fiskus haruslah berlandaskan pada undang-undang negara dan peraturan- peraturannya. Hukum Pajak ataupun undang-undang yang mengatur soal pemungutan pajak itu merupakan kepastian hukum yang memberi jaminan hukum itu penting sekali untuk menyatakan keadilan yang tegas. Pemungutan pajak oleh fiskus itu mempunyai hubungan erat dengan soal-soal hak asasi manusia. Misalnya fiskus memungut pajak tanpa dasar hukum atau undang-undang, tindakannya tidak saja dapat merugikan wajib pajak tetapi juga negara. Pemungutan pajak yang dijiwai dorongan exploitation de l'homnie par' homme akan meruntuhkan kewibawaan negara di mata rakyatnya. Indonesia sebagai negara hukum, maka pemungutan pajak dicantumkan dalam UndangUndang Dasar Negara Republik Indonesia Tahun 1945 Pasal 23 ayat (2) yang berbunyi : "Segala pajak untuk keperluan Negara berdasarkan Undang-undang". Sebagai konsekuensi dari pasal tersebut wajib pajak harus mendapat jaminan hukum sehingga mereka itu tidak diperlakukan sewenang-wenang.

2. Asas keadilan yang pada prinsipnya pajak hendaknya bersifat umum atau universal dan ini berarti bahwa pajak tidak boleh diskriminatif artinya sesorang dalam keadaan yang sama hendaknya diperlakukan yang sama pula. Asas keadilan ini juga mengandung persamaan beban, artinya seseorang hendaknya dikenakan beban yang sama dengan orang lain yang dalam keadaan sama pula dan dalam pengenaan pajak hendaknya memperhatikan daya pikul atau kemampuan membayar seseorang.

3. Asas ekonomi yang pada prinsipnya pemungutan pajak merupakan suatu alat untuk menentukan politik perekonomian suatu negara dan sesuai dengan asas keadilan, karena rakyat tidak boleh dipungut dengan pajak-pajak berat yang dapat menyulitkan kehidupan sehari-harinya, walaupun memang pajak-pajak ini hasilnya adalah untuk digunakan mencapai kesejahteraan umum. Oleh karena itu, suatu pemungutan pajak yang diselenggarakan oleh negara haruslah mengandung pengertian 
bahwa adanya pemungutan pajak itu jangan sampai ia menghambat lalu lintas perdagangan dan daftar produksi, artinya pajak-pajak itu tidak boleh membuat perdagangan dan hasil produksi menjadi macet; adanya pemungutan pajak diusahakan jangan sampai merugikan kepentingan umum; pajak itu harus dapat dibayar dari penghasilan rakyat; pajak itu harus dipungut dari rakyat dalam waktu yang paling tepat. Hal-hal tersebut di atas sedapat mungkin harus diperjuangkan penyelenggaraannya, sehingga tidak akan terjadi karena pemungutan pajak maka kepentingan umum dirugikan.

4. Asas finansial yang berarti bahwa negara memungut pajak itu tidak lain adalah untuk memperoleh biaya pengeluaran negara. Di dalam melaksanakan pemungutan pajak itu haruslah biaya pemungutannya ditekan seminimal mungkin, karena tidak ada gunanya mengadakan pemungutan pajak bilamana biaya pemungutan sangat tinggi. Asas finansial ini juga mengandung pengertian/pemikiran, bahwa fiskus dalarn melaksanakan pemungutan pajak, haruslah mengenakannya pada suatu saat/waktu yang tepat bagi wajib pajak, jangan terlalu jauh dan jangan terlalu dekat dengan suatu kejadian di mana bagi wajib pajak diharuskan melakukan pembayaran pajak. Selain hal tersebut, asas finansial ini juga mengandung pemikiran, bahwa apabila terdapat suatu peraturan pajak yang tidak sesuai lagi dengan keadaan maka dalarn pencabutan peraturan pajak itu, fiskus haruslah meneliti kembali apakah dengan mencabutnya peraturan pajak itu bakal mengurangi anggaran belanja negara atau tidak. Sebab jika anggaran belanja tidak mengijinkan, sudah tentu untuk sementara waktu pajak tadi dipertahankan.

\section{Teori-Teori Pemungutan Pajak}

Ada dua teori yang digunakan sebagai dasar yang menghalalkan negara mengambil pajak untuk kesejahteraan umum (Yusuf Qardawi, 1990 : 29), yaitu:

1. Teori Perjanjian yang mengajarkan bahwa pemungutan pajak diwajibkan atas dasar hubungan timbal-balik negara dengan anggota masyarakat. 
Teori ini memandang bahwa pajak itu dibayar sebagai imbalan jasa yang diperoleh pemilik harta berupa perlindungan atas segala kepentingan umum, dengan mewajibkan mengadakan perjanjian perlindungan wajib antara negara dengan warganya. Buah pikiran ini adalah didasarkan teori "perjanjian sosial" yang dikatakan oleh Jean Jacques Rousseau mengenai asas negara. Pendukung teori timbal-balik mengenai perjanjian alamiah yang kokoh antara negara dengan pembayar pajak mengemukakan berbagai aliran. Mirabau berpendapat: "Pajak adalah pembayaran di muka yang dilakukan oleh seseorang terhadap perlindungan sekelompok manusia. Ini berarti bahwa perjanjian itu berbentuk akad jual beli”, sedangkan Adam Smith menilai bahwa "Perjanjian ini berbentuk pembayaran jasa atas pekerjaan. Negara memberikan berbagai pelayanan bagi warganya, maka warga negara membayar pajak kepada negara sebagai imbalan atas pekerjaan-pekerjaannya." Montesque dan Hobes berpendapat bahwa "Perjanjian ini berbentuk jaminan keamanan, dengan demikian pajak adalah bagian harta yang wajib diserahkan oleh pemilik kekayaan untuk melindungi keamanan hartanya."

2. Teori kedaulatan negara. Teori ini mempunyai pandangan bahwa negara melakukan fungsinya untuk melayani kebutuhan masyarakat, tidak untuk kepentingan pribadi. Oleh karena itu kepentingan umum didahulukan atas kepentingan pribadi serta perlu menjaga kepentingan nasional untuk generasi masa kini dan masa yang akan datang. Untuk melaksanakan fungsinya, negara memerlukan pembiayaan oleh karena itu negara mempunyai hak untuk mewajibkan penduduknya atas dasar kedaulatan menanggung pembiayaan itu sesuai dengan tingkat kemampuan masing-masing warganya, atas dasar prinsip " pembelaan sosial" yang digunakan oleh golongan politik modern (Yusuf Qardawi, 1990 : 129).

Perbedaan pandangan ini akan menjadi jelas, jika dlilihat dari perkembangan sejarah tentang asas dan teori-teori pajak, bahwa pemungutan pajak berasaskan keadilan dan kesejahteraan itu bukanlah merupakan persoalan baru dan dari berbagai teori untuk membenarkan serta memberi 
dasar hukum pada pemungutan pajak oleh negara dengan meyakinkan bahwa pemungutan tersebut adalah halal dan sekali-kali janganlah dilihat sebagai suatu perampasan yang sewenang-wenang.

Selain teori pemungutan pajak berdasarkan teori perjanjian dan teori kedaulatan negara masih ada penggolongan teori pemungutan pajak berdasarkan literatur ilmu keuangan negara (Bohari, 2002 : 36), yaitu teoriteori yang memberikan dasar pembenaran atau landasan filosofis negara untuk memungut pajak yang dapat dipaksakan. Teori-teori tersebut adalah :

1. Teori Asuransi di mana menurut teori ini negara dalam melaksanakan tugasnya/fungsinya, mencakup pula tugas perlindungan terhadap jiwa dan harta benda perseorangan. Oleh sebab itu negara bekerja atau bertindak sebagai perusahaan asuransi. Untuk perlindungan itu warga membayar premi, dan pembayaran pajaklah yang dapat dipandang sebagai premi. Teori ini sudah lama ditinggalkan dan sekarang praktis tidak ada lagi pembelanya, sebab negara tidak mengganti kerugian bila timbul kerugian atas orang-orang yang bersangkutan, misalnya dibunuh atau hartanya dicuri.

2. Teori kepentingan di mana menurut teori ini pajak itu mempunyai hubungan dengan kepentingan individu yang diperoleh dari pekerjaan negara. Makin banyak mengenyam atau menikmati jasa dari pekerjaan pemerintah, makin besar juga pajaknya. Teori ini meskipun masih berlaku pada retribusi, tetapi sulit diterima sebab orang miskin dan penganggur yang memperoleh bantuan dari pemerintah, menikmati atau mengenyam banyak sekali jasa dari pekerjaan pemerintah dan mereka bahkan dibebaskan membayar pajak.

3. Teori kewajiban pajak mutlak atau teori pengorbanan yang berpangkal tolak dari ajaran organik kenegaraan (organische staatsleer) yang berpendirian bahwa tanpa negara maka individu tidak mungkin bisa hidup bebas berusaha dalam negara. Oleh karena itu negara mempunyai hak mutlak untuk memungut pajak. Tanpa negara, individu pun tidak ada sehingga pembayaran pajak oleh individu kepada negara dipandang 
sebagai tanda pengorbanan atau tanda baktinya. Teori ini terlalu menitikberatkan kepada negara, seolah-olah individu tidak dapat hidup tanpa negara tetapi negara dapat hidup tanpa individu. Pada kenyataanya tidak demikian sebab negarapun tak mungkin hidup /ada tanpa individu.

4. Teori gaya beli yang mengajarkan bahwa fungsi pemungutan pajak jika dipandang sebagai gejala dalam masyarakat disamakan dengan pompa, yaitu mengambil gaya beli dari rumah tangga dalam masyarakat untuk rumah tangga negara dan kemudian menyalurkan kembali ke masyarakat dengan tujuan untuk memelihara hidup masyarakat atau untuk kesejahteraan masyarakat secara keseluruhan.Teori gaya beli ini banyak penganutnya karena kepraktisannya. Teori ini berlaku sepanjang masa baik dalam ekonomi liberal maupun dalam masyarakat sosialis. Teori ini tidak mempersoalkan asal mula negara memungut pajak, melainkan hanya melihat kepada efek yang baik sebagai dasar keadilannya. Menurut teori ini maka penyelenggaraan kepentingan masyarakat itulah yang dapat dianggap sebagai dasar keadilan pemungutan pajak dan bukan kepentingan individu dan bukan kepentingan negara, melainkan kepentingan masyarakat yang meliputi keduanya.

5. Teori gaya pikul mengajarkan bahwa pemungutan pajak harus sesuai dengan kekuatan membayar dari si wajib pajak (individu). Pemungutan semua pajak harus sesuai dengan gaya pikul si wajib pajak dengan memperhatikan pada besarnya penghasilan dan kekayaan serta pengeluaran belanja wajib pajak tersebut. Dengan demikian teori gaya pikul ini dipengaruhi oleh bermacam-macam komponen, antara lain: pendapatan; kekayaan; dan susunan dari keluarga wajib pajak dengan memperhatikan faktor-faktor yang mempengaruhi keadaannya.

Penulis berpendapat bahwa gaya pikul itu ada bila kekuatan untuk membayar uang kepada negara dalam bentuk pajak setelah dikurangi dengan minimun kehidupan atau kebutuhan dasar (basic needs) atau dengan kata lain kekuatan untuk menyerahkan uang kepada negara barulah ada jika kebutuhan-kebutuhan primer untuk hidup telah tersedia. Teori-teori di atas 
merupakan pembenaran pemecahan pemungutan pajak oleh negara sehingga para ahli dibidang keuangan negara umumnya dan dibidang perpajakan khususnya menamakannya sebagai asas menurut falsafah hukum.

\section{Reformasi Birokrasi Direktorat Jenderal Pajak sebagai Wujud Pelayanan Prima terhadap Wajib Pajak}

Syarat mutlak menuju kemandirian bangsa adalah dengan meningkatkan peran serta aktif seluruh masyarakat melalui pembayaran pajak. Salah satu usaha meningkatkan penerimaan negara dari sektor pajak adalah melalui implementasi good governance sehingga mampu memberikan pelayanan prima di lingkungan Direktorat Jenderal Pajak (DJP). Good governance dan pelayanan prima dapat dicapai dengan modernisasi yang dilakukan secara komprehensif dan simultan hingga menyentuh instrumen perpajakan lainnya seperti sistem, institusi, pelayanan kepada masyarakat wajib pajak, pengawasan terhadap pemenuhan kewajiban perpajakan. Hal yang tidak kalah penting dalam menunjang pelayanan prima adalah moral, etika, dan integritas petugas pajak.

1. Sejarah Perkembangan Kantor Pelayanan Pajak (KPP)

a. KPP Pra Modern

DJP sebenarnya telah melakukan reformasi pada tahun 1983 yaitu pada sistem pemungutan pajak yang semula Official Assessment System menjadi Self Assesment System. Saat itu, Kantor Pajak masih disebut sebagai Kantor Inspeksi Pajak. Kemudian pada tahun 1989, Kantor Inspeksi Pajak diganti namanya menjadi Kantor Pelayanan Pajak (KPP) yang menjalankan fungsi pelayanan untuk jenis Pajak Penghasilan (PPh) dan Pajak Pertambahan Nilai (PPN). Sementara pelayanan Pajak Bumi dan Bangunan (PBB) dan Bea Perolehan Hak Atas Tanah dan/atau Bangunan (BPHTB) dilakukan oleh Kantor Pelayanan Pajak Bumi dan Bangunan (KPPBB). Selain fungsi pelayanan, DJP juga menjalankan fungsi pemeriksaan yang dilakukan oleh Kantor Pemeriksaan dan Penyidikan Pajak (Karikpa). Sebelum tahun 1994, Karikpa ini disebut sebagai Unit Pemeriksaan dan Penyidikan Pajak (UP3). Sedangkan fungsi penyuluhan 
dilakukan oleh Kantor Penyuluhan dan Pengamatan Potensi Perpajakan (KP-4) yang sebelum tahun 2001 disebut Kantor Penyuluhan.

Struktur organisasi pada fungsi pelayanan di KPP Pra Modern ini didasarkan atas jenis pajak; seperti Seksi PPh Badan, PPh Perseorangan, PPh Pemotongan Pemungutan, dan PPN. Pada struktur ini, fungsi pelayanan sekaligus pemeriksaan dilakukan oleh KPP, sementara fungsi pemeriksaan juga dilakukan oleh Karikpa, Fungsional Kantor Wilayah (Kanwil), dan Fungsional Kantor Pusat DJP, sehingga terjadi fungsi yang saling tumpang tindih. Di samping itu, pelayanan belum bersifat satu atap (one stop service) karena mengingat jenis pajak $\mathrm{PPh}$ dan PPN diadministrasikan oleh KPP, sedangkan jenis pajak PBB dan BPHTB oleh KPPBB.

Pengaduan atau pengajuan keberatan diproses di KPP namun juga dilakukan di Kanwil dan Kantor Pusat DJP, sehingga memunculkan dualisme fungsi. Dualism ini timbul karena baik pemeriksaan maupun proses penyelesaian keberatan dilakukan oleh KPP. Hal-hal inilah yang mendorong dibentuknya KPP Modern.

b. KPP Modern

Modernisasi perpajakan DJP melalui jalan yang panjang sejak tahun 2002 hingga sekarang. Pertama, pada tahun 2002 Menteri Keuangan Republik Indonesia mengeluarkan keputusan dengan No 65/KMK.01/2002 tentang pembentukan dua KPP LTO (Large Taxpayers Office) yang kemudian disebut KPP WP BESAR yang berdomisili di Jakarta. KPP WP BESAR ini melayani masing-masing sebanyak 300 WP Badan terbesar di seluruh Indonesia dan hanya mengadminstrasikan jenis Pajak PPh dan PPN.

Kedua, pada tahun 2003 dengan diterbitkannya Kepmenkeu No 519/KMK.01/2003 jo. 587/KMK.01/2003, dibentuk sepuluh KPP KHUSUS yang berdomisili di Jakarta; meliputi KPP BUMN, Perusahaan PMA, WP Badan dan Orang Asing, dan Perusahaan Masuk Bursa. KPP Khusus ini hanya mengadiminstrasikan jenis Pajak PPh dan PPN. 
Ketiga, pada tahun 2004 berdasarkan Kepmenkeu No 254/KMK.01/2004 dibentuk KPP MTO (Medium Taxpayers Office) yang kemudian disebut KPP MADYA yang berjumlah satu buah di setiap Kanwil dan sepuluh di Kanwil Khusus dengan total 32 KPP Madya di seluruh Indonesia. Jumlah masing-masing WP KPP Madya sebanyak 200500 perusahaan terbesar di tingkat wilayah Kanwil tersebut, KPP Madya juga hanya mengadministrasikan jenis Pajak PPh dan PPN.

Keempat, pada tahun 2006 hingga 2008 dibentuk KPP Small Taxpayers Office (STO) yang kemudian disebut KPP PRATAMA dengan total 357 KPP Pratama di seluruh Kanwil. KPP Pratama bertugas melayani WP Badan menengah ke bawah dan WP Orang Pribadi; dan memberikan pelayanan pajak meliputi jenis pajak PPh, PPN, PBB, dan BPHTB.

Dalam struktur yang modern ini terdapat perbedaan yang cukup radikal dan signifikan, khususnya pada struktur organisasi KPP. Struktur organisasi KPP Pra Modern yang berdasarkan jenis pajak diubah menjadi berdasarkan fungsi pada KPP Modern. Hal ini dilakukan guna debirokratisasi pelayanan, sehingga Seksi Pelayanan dan Seksi Pemeriksaan dibentuk secara terpisah.

Pelayanan perpajakan pun sudah mulai dilakukan satu atap (one stop service) karena semua jenis pelayanan perpajakan, baik jenis pajak $\mathrm{PPh}$, PPN, PBB, dan BPHTB, dilakukan di KPP Pratama sehingga menyebabkan adanya peleburan KP.PBB ke KPP Pratama. Sementara KPP WP Besar dan KPP Madya hanya jenis pajak PPh dan PPN.

Pada struktur organisasi KPP Modern ini, proses penyelesaian keberatan hanya dilakukan di tingkat Kanwil, mengingat di Kanwil tidak lagi menjalankan fungsi pemeriksaan karena fungsi pemeriksaan sepenuhnya dilaksanakan oleh KPP Modern. Adanya fungsi pemeriksaan yang dilakukan KPP Modern secara penuh inilah yang menyebabkan dileburnya Karikpa ke KPP Modern.

2. Pelayanan Prima KPP Modern 
Dengan model KPP Modern seperti diuraikan di atas diharapkan DJP dapat memberikan pelayanan prima kepada masyarakat dalam masalah perpajakan. Untuk mensukseskan pelayanan prima tersebut DJP telah menyiapkan pelayanan ekstra pada setiap KPP Modern.

Pelayanan ekstra yang disediakan oleh KPP Modern ini antara lain dengan tersedianya Account Representatives (AR) sebagai ujung tombak pelayanan dan perantara antara DJP dengan WP yang mengemban tugas melayani setiap Wajib Pajak dalam berbagai hal; antara lain (1) membimbing/menghimbau WP dan memberikan konsultasi teknis perpajakan; (2) memonitor penyelesaian pemeriksaan pajak, proses keberatan, serta mengevaluasi hasil banding; (3) melakukan pemuktahiran data WP dan menyusun profil WP; (4) menginformasikan ketentuan perpajakan terbaru; (5) memonitor kepatuhan WP melalui pemanfaatan data \& Sistem Administrasi Perpajakan Terpadu (SAPT); (6) menyelesaian permohonan surat keterangan yang diperlukan WP; (7) menganalisis kinerja wajib pajak; dan (8) merekonsiliasi data WP dalam rangka intensifikasi. Dengan demikian setiap WP dapat menanyakan hak dan kewajiban perpajakannya kepada setiap AR di KPP Pratama yang telah ditunjuk untuk masing-masing WP sesuai dengan wilayah kelurahan domisili WP.

Di samping tersedianya AR yang dapat melayani WP di setiap KPP, DJP juga membentu layanan contact center yang terdiri atas complain center, call center, dan non filers activation center. Media penyampaian pengaduan pada layanan contact center ini dapat melalui e-mail, pos, nomor telpon bebas biaya, atau datang secara langsung. Pengaduan yang diterima oleh complain center akan dikoordinasikan dengan unit terkait dan akan ditindaklanjuti dalam waktu 3 hari kerja. Jenis-jenis pengaduan yang dilayani termasuk mengenai pelayanan, konsultasi, pemeriksaan, keberatan maupun banding.

Sarana, prasarana, dan pendukung lainnya yang lebih modern juga disediakan demi mendukung pelayanan prima KPP Modern. Sarana 
pendukung pelayanan tersebut misalnya Help Desk dengan teknologi knowledge-based pada Tempat Pelayanan Terpadu atau TPT (service counter). Demi kemudahan WP, DJP juga melayani dengan menggunakan sistem komunikasi dan teknologi informasi terkini yang dikenal dengan sebutan e-system; antara lain e-payment (pembayaran pajak secara on line), e-registrasion (pendaftaran wajib pajak melalui internet), e-filling (pelaporan pajak melalui internet), e-spt (pengisian SPT dengan program yang telah disediakan DJP), dan e-counseling (konsultasi secara online). Sistem teknologi informasi juga digunakan dalam pengawasan internal dan pengawasan data yaitu berupa Built in control system.

Pelayanan pajak di KPP Modern kini didukung petugas pajak yang berkualitas tinggi dan berbasis kompetensi, serta dituntut untuk senantiasa menerapkan Kode Etik Pegawai yang diawasi oleh Komite Kode Etik Pegawai, Komisi Ombudsman Nasional, Tim Khusus Inspektorat Jenderal Departemen Keuangan, dan dua Subdirektorat Kantor Pusat DJP yang menangani Pengawasan Internal. Sistem pengawasan ini juga didukung dengan sistem remunerasi yang lebih baik bagi pegawai dengan adanya Tunjangan Kegiatan Tambahan (TKT).

Kemudahan dan ketersediaan informasi bagi WP merupakan salah satu bentuk pelayanan prima KPP Modern. Informasi ini dapat diperoleh dengan mudah oleh WP melalui layar sentuh informasi perpajakan (Touch Screen), brosur, leaflet, dan majalah perpajakan. Sistem antrian dan LCD Proyektor berikut electric screen layaknya pelayanan di Bank juga telah diterapkan di KPP Modern demi kenyamanan WP ketika melakukan transaksi perpajakan. Di samping itu, tersedia pula ruang konseling/closing conference bagi WP sehingga WP dapat merasa lebih aman dan nyaman saat menerima konseling. KPP Modern juga bekerja sama dengan Bank, PEMDA setempat, serta Kantor Pos sebagai Tempat Pembayaran Pajak resmi selain KPP. Dengan berbagai layanan dan sarana pendukung ini 
diharapkan DJP mampu memberikan pelayanan prima kepada WP sesuai dengan tujuan yang diharapkan.

\section{Fokus Ekstensifikasi KPP Modern}

Sampai saat ini, struktur penerimaan pajak di Indonesia yang berasal dari WP Orang Pribadi masih sangat kecil (28\%), dibandingkan dengan beberapa negara maju seperti Amerika Serikat (86\%), Jepang (60\%), Filipina $(37 \%)$, Thailand $(36 \%)$, sementara persentase terbesar masih bersumber jenis pajak PPh dan PPN. Persentase itupun (28\%) merupakan hasil akumulatif kontribusi dari PPh Pasal 21 Karyawan, PPh Pasal 25 Angsuran, dan PPh Pasal 29 Kurang Bayar Akhir Tahun Perseorangan (Makalah Modernisasi Administrasi Perpajakan KPP Pratama, Kantor Pusat DJP)

Secara nasional jumlah WP Orang Pribadi yang terdaftar di Indonesia masih sangat sedikit, yaitu 2,9 juta NPWP (Nomor Pokok Wajib Pajak) pribadi dari sekitar 220 juta penduduk, (Majalah Berita Pajak Vol. XXXIV No 1584, 1 April 2007). Pada masa modernisasi pajak kali ini ekstensifikasi perpajakan difokuskan kepada karyawan melalui pemberi kerja dan bendaharawan pemerintah; non karyawan dengan dasar property-based yang sasarannya adalah pertokoan, mall, pusat perdagangan, perumahan, apartemen, dan lainnya; serta professionalbased yang sasarannya adalah dokter, notaris/PPAT, pengacara, artis, dan sebagainya. Ekstensifikasi perpajakan ini dimaksudkan agar lebih tepat sasaran.

4. Kode Etik Pegawai Direktorat Jenderal Pajak (DJB)

Reformasi perpajakan di segala lini yang telah disusun oleh DJP akan sia-sia jika tidak didukung baik eksternal maupun internal. Sebagai bukti keseriusan pemerintah dalam modernisasi pajak, pemerintah memberlakukan adanya perimbangan reward dan punishment serta penegakan ketertiban etika, moral, dan integritas petugas pajak. DJP telah menyusun Kode Etik Pegawai DJP yang diatur dalam Permenkeu No 1/PMK.3/2007 tanggal 23 Juli 2007 tentang sembilan kewajiban pegawai 
dan delapan larangan pegawai baik kepada masyarakat WP, sesama pegawai, atau pihak lain, dengan sanksi setinggi-tingginya pemberhentian dengan tidak hormat dan serendah-rendahnya pernyataan tidak puas secara tertulis. Tercatat selama tahun 2006 terdapat 210 pegawai pajak yang telah dijatuhkan sanksi disiplin dan sebanyak 31 orang selama Januari 2007 (Majalah Berita Pajak Vo. XXXIV No 1583, 15 Maret 2007).

Ekspektasi dari modernisasi pajak adalah meningkatkan kepatuhan (tax compliance), menurunkan keluhan, menurunkan biaya administrasi, menekan/minimalisasi penggelapan pajak, meningkatkan kepercayaan terhadap administrasi perpajakan, serta meningkatkan integritas dan produktivitas pegawai pajak.

\section{Simpulan}

1. Rendahnya kesadaran masyarakat dalam membayar pajak dikarenakan tidak pahamnya masyarakat tentang fungsi pajak dan perilaku pemungut pajak yang tidak professional.

2. Usaha peningkatan kesadaran membayar pajak melalui pendidikan formal dapat dilakukan dengan cara membuat kurikulum pendidikan dengan memuat materi perpajakan dari mulai pendidikan pra sekolah, pendidikan dasar, pendidikan menengah, hingga pendidikan tinggi.

\section{Daftar Pustaka:}

Anderson WH. 1981. Taxation and The America Economy. New York: Printice Hall.

Bohari. 2002. Pengantar Hukum Pajak. Jakarta : Rajagrafindo Persada

Djajaningrat, Sindian Isa. 1995. Hukum Pajak dan Keadilan, Bandung : Eresco.

Glenn P. Jenkins dan Gangadhar P. Shukla, 1997, Public Finance in Open Economies. Harvard International Tax Program. Harvard Institute for International Development

Hector S. De Leon. 1993. The Fundamentals of Taxation. Manila: Rex Book Store.

Lewis. A. 1982. The Psychology of Taxio. Oxford: Martin Robertson. 
Richard, Bird., and Oliver Oldman. 1964. Reading On Taxation In Developing Countries. Baltimore: The Johns Hopkins Press.

Sofyan, Marcus Taufan. 2000. Pengaruh Penerapan Sistem Administrasi Perpajakan Modern Terhadap Kepatuhan Wajib Pajak Pada Kantor Pelayanan Pajak Di Lingkungan Kantor Wilayah Direktorat Jendral Pajak Wajib Pajak Besar, Skripsi. Tangerang, Sekolah Tinggi Akuntansi Negara.

Soemitro, Rochmat. 1990. Pajak Penghasilan., Bandung: Eresco. 1991. Pajak ditinjau dari Segi Hukum. Bandung : Eresco. 1992. Makalah pada Program Notariat UNDIP. Semarang.

Qardawi, Yusuf. 1990. Hukum Zakat. Jakarta : Litera Antar Nusa.

Wiwoho, Jamal. 2008, Membangun Model Penyelesaian Sengketa Pajak yang Berkeadilan. Surakarta: UNS Press.

\section{Jurnal:}

Liberty Pandiangan. 2002. Pajak Pusat dan Pajak Pusat dalam Kerangka Sistem Perpajakan Nasional. Jurnal Perpajakan Indonesia. Vol 1, No. 7 